\title{
Rare gain of chromosome 5 in a supratentorial hemispheric paediatric pilomyxoid astrocytoma
}

\author{
Katherine Clark Pehlivan, ${ }^{1}$ Denise M Malicki, ${ }^{2}$ Michael L Levy, ${ }^{3}$ John Ross Crawford ${ }^{4}$
}

'Department of Neurosciences, University of California San Diego, San Diego, California, USA

${ }^{2}$ Department of Pathology, Rady Children's Hospital University of California San Diego, San Diego, California, USA

${ }^{3}$ Department of Neurosurgery, University of California San Diego, San Diego, California, USA

${ }^{4}$ Department of Neurosciences and Pediatrics, University of California San Diego, San Diego, California, USA

Correspondence to Dr John Ross Crawford; jrcrawford@ucsd.edu

Accepted 4 March 2020
Check for updates

(C) BMJ Publishing Group Limited 2020. No commercial re-use. See rights and permissions. Published by BMJ.

\begin{tabular}{l}
\hline To cite: Pehlivan KC, \\
Malicki DM, Levy ML, \\
et al. BMJ Case Rep \\
2020;13:e234878. \\
doi:10.1136/bcr-2020- \\
234878 \\
\hline
\end{tabular}

\section{DESCRIPTION}

A previously healthy 11-year-old boy presented with self-limited recurrent episodes of dizziness, disorientation and visual changes with a normal neurological examination. MRI revealed a wellcircumscribed mixed solid/cystic left parietooccipital mass (figure 1). He underwent a gross total resection where neuropathology demonstrated moderately cellular proliferation of bland bipolar process-forming spindle cells in a myxoid background with focal angiocentric arrangement, and absence of Rosenthal fibres, consistent with a diagnosis of pilomyxoid astrocytoma (PMA) (figure 2). DNA-based next-generation sequencing panel consisting of 397 cancer-related genes (table 1) performed on paraffin-embedded formalin-fixed tumour revealed no reportable mutations and variants of unknown significance of PMS1 and RB1. However, chromosomal microarray analysis revealed a gain of chromosome 5 . The patient was treated with surgery only and is currently 3 years without evidence of recurrence and a normal neurologic examination.

PMAs are currently categorised as a distinct variant of pilocytic astrocytomas (PAs). The 2016 WHO classification of tumours of the central nervous system does not assign a grade to PMAs, but these neoplasms often have a more aggressive clinical course, higher recurrence rates and shorter progression free survival than PAs. ${ }^{1}$ As with conventional PAs, BRAF-KIAA fusions are the most common genetic alteration, followed by other alterations in the mitogen-activated protein kinase pathway. The majority of paediatric PAs and PMAs have normal tumour cytogenetics. Single copy number alterations, including gains of chromosome 5 , have been reported previously in rare paediatric and adult cases of PA. ${ }^{2}$ Gain of chromosome 5 has also been reported in one prior mixed-type PMA/ PA but this case has clear delineation between the

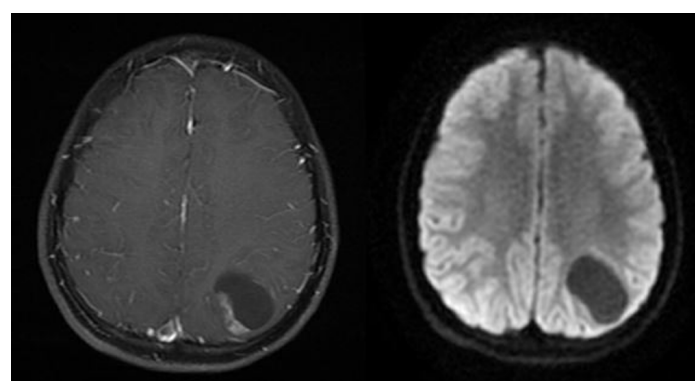

Figure 1 MRI showing T1 postcontrast and diffusionweighted axial images of mixed solid/cystic parietooccipital brain mass.



Figure 2 H\&E-stained sections showed a moderately cellular proliferation of bland bipolar process-forming spindle cells in a myxoid background with focal angiocentric arrangement consistent with a diagnosis of pilomyxoid-variant astrocytoma (200x).

pilomyxoid and non-pilomyxoid components of the tumour, and the copy number gain of chromosome 5 was only seen in the non-pilomyxoid component of tumour and was distinctly absent in the pilomyxoid component which only showed a gain of chromosome 11.

To the best of our knowledge, this case represents the first report of single-copy number gain of chromosome 5 in a paediatric PMA. This case underscores the overlap of the genetic landscape of pilomyxoid and pure PAs. While tumour genetics may not clearly differentiate PMAs from typical PAs, tumour genomic studies are indicated in the work up of these tumours due to the high frequency of targetable molecular alterations and to gain a better understanding of the molecular drivers behind their biology. This gain of chromosome 5 in the absence

\section{Learning points}

- Gain of chromosome 5 can occur as a single copy number variant in paediatric pilomyxoid astrocytoma.

- There is overlap in the genomic landscape of classic paediatric pilocytic astrocytoma and the pilomyxoid variant.

- Tumour genomic testing, including nextgeneration sequencing and chromosomal microarray, may elucidate pharmacologically targetable mutations but also contributes to the understanding of molecular biology of these tumour types. 
Images in...

Table 1 Next-generation cancer gene panel



of other copy number variants and clinically significant mutations identified on next-generation sequencing suggests gain of chromosome 5 as a potential genomic alteration sufficient to drive tumorigenesis.

Contributors $\mathrm{KCP}, \mathrm{DMM}, \mathrm{MLL}$ and JRC were responsible for the design and writing of the manuscript and approval of its content.

Funding The authors have not declared a specific grant for this research from any funding agency in the public, commercial or not-for-profit sectors.

Competing interests None declared.
Patient consent for publication Parental/guardian consent obtained.

Provenance and peer review Not commissioned; externally peer reviewed.

\section{REFERENCES}

1 Louis DN, Ohgaki K, Wiestler OD, et al. WHO classification of tumours of the central nervous system. Revised 4th edn. IARC, Lyon, 2016. ISBN: 978-92-832-4492-9.

2 Jeon Y-K, Cheon J-E, Kim S-K, et al. Clinicopathological features and global genomic copy number alterations of pilomyxoid astrocytoma in the hypothalamus/ optic pathway: comparative analysis with pilocytic astrocytoma using array-based comparative genomic hybridization. Mod Pathol 2008;21:1345-56.

3 Kulac I, Tihan T. Pilomyxoid astrocytomas: a short review. Brain Tumor Pathol 2019;36:52-5. 
Copyright 2020 BMJ Publishing Group. All rights reserved. For permission to reuse any of this content visit https://www.bmj.com/company/products-services/rights-and-licensing/permissions/

BMJ Case Report Fellows may re-use this article for personal use and teaching without any further permission.

Become a Fellow of BMJ Case Reports today and you can:

- Submit as many cases as you like

- Enjoy fast sympathetic peer review and rapid publication of accepted articles

Access all the published articles

Re-use any of the published material for personal use and teaching without further permission

Customer Service

If you have any further queries about your subscription, please contact our customer services team on +44 (0) 2071111105 or via email at support@bmj.com.

Visit casereports.bmj.com for more articles like this and to become a Fellow 